\title{
Access to capital in Northern Ontario: Are we getting it right?
}

\author{
Geoff Gillon, Ec.D.
}

\begin{abstract}
Since the late 1970s, Northern Ontario's mining, forest and tourism industries have been declining. Various programs through Industry Canada/FedNor and the Ministry of Northern Development and Mines (MNDM) have addressed this problem by providing access to capital. This paper outlines and examines the programs in place, discussing their function and evaluation structures. The author concludes that a long-term strategy must be in place to support businesses through the economic ups and downs of the region and calls for Canada and Ontario to work more closely together to increase efficiencies, improve expertise and provide better service for their business clients.
\end{abstract}

Keywords: Ministry of Northern Development and Mines (MNDM), FedNor, Northern Ontario, access to capital

\section{Introduction}

Economic uncertainty crept across the Northern Ontario landscape in the late 1970s and early 1980s as increased automation, rising fuel costs and a high Canadian dollar dramatically affected the mining, forest and tourism industries. Labour force reductions and business closings signaled a major restructuring of the north's economy. This fact was highlighted by an Advisory Committee headed by Dr. Robert Rosehart of Lakehead University in their study of resource dependent communities in 1986. The Committee, which traveled extensively across the region, made over 90 recommendations to government on actions needed to bolster the northern economy. Many of these recommendations were implemented by the government of the day, such as the re-location of some government offices from Toronto to the north. Unfortunately, after two decades, the economy of Northern Ontario continues to restructure and decline. In fact the region's population declined by over 40,000 people between 1996 and 2001, as compared to the dramatic growth in Greater Toronto Area (GTA) which experienced a 9.8 percent increase in the same period (NTAB, 2002; Ministry of Finance, 2001). With the closings in the fall of 2005 of paper mills in places such as Kenora, Thunder Bay and Red Rock the process of restructuring will continue well into the future. In response to these economic conditions senior governments have created a number of programs in an attempt to stem or stabilize the economic decline observed in Northern Ontario since the 1980s.

In addition to having to cope with changing economic conditions, Northern Ontario businesses, like all Canadian businesses, face the challenge of dealing with banks. It is clear that there are 
issues around the ability or desire of the major banks to lend to small business. The actions taken by Canada's major banks during the recession of the early 1990s have made business wary of future measures. CFIB states that "small business owners who were abandoned by their bank are reluctant to put themselves in that situation again" (CFIB, 2003). For example major bank lending to small businesses seeking loans or lines of credit under $\$ 200,000$ has been static for almost twenty years (Ibid). This is astounding as the Canadian economy has grown steadily from the early 1990s. Given this credit environment, access to government capital programs can be seen as a response to a financial environment which did not appear to support the provision of capital to business. Despite being faced with reduced credit options at the major banks, Small and Medium Enterprises (SME) appear to send mixed messages to government. A report authored by S. Albert-Doucet (1997) stated that while some "small businesses tend to view bank financing arrangements as inhospitable to their needs" others "were relatively pleased with their banking institutions". It can be safely assumed that all businesses experience issues with accessing capital and or credit at some point in time. Figure 1 indicates that concerns about credit rose dramatically from a low of 15 percent in 1988 to a high of over 35 percent by 1994 (CFIB, 2005). Yet the issue of financing usually ranked no higher than seventh as a concern of CFIB members throughout the period, well below other issues such as government regulations and tax burden (Ibid). It appears that even though a third of businesses had financing problems it was not the single most important issue to them as a whole. This is an indication that access to capital can be a very personal experience. This supports the statement on the Albert-Doucet Report citing the ambiguity within the business community on the issue of access to capital.

The government appears to have elected to act on the concerns of those having issues accessing capital. Although not identified as access to capital until recently this issue was recognized as a problem as early as the late 1970s. As a result, successive federal and provincial governments have continually developed, modified and terminated programs designed to enhance access to financial capital for the regional businesses. The paper will outline a short history of the various programs created by government in an attempt to address the issue of access to capital. The focus will be on programs available through Industry Canada/FedNor and the Ministry of Northern Development and Mines (MNDM) or their precursors. The essence of the discussion will be on whether the issue of access to capital is really understood and provided in a functional form. The paper will also examine whether this measure is being used appropriately and being properly evaluated. 
Figure 1: SMEs citing concerns about availability of credit, 1984 to 1997

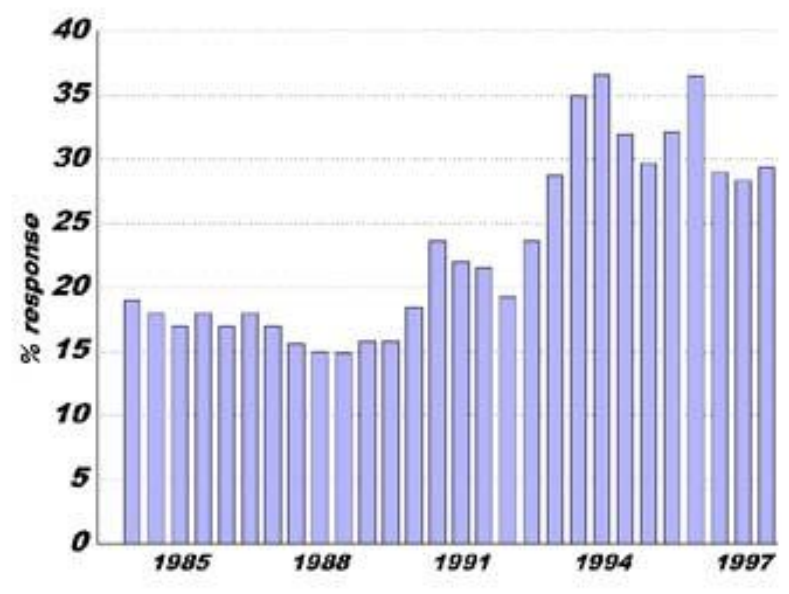

Source: (Mallett, 1998)

\section{Access to capital: The federal response}

Access to capital in Northern Ontario has been addressed at the federal level by only two parties, the Progressive Conservatives from 1983 to 1993 and the Liberals from 1993 to 2006. Both governments developed policies in an effort to stimulate business growth and create jobs in the region. In response to the downward trend in employment across Northern Ontario and other rural regions, the federal government through Employment and Immigration Canada (EIC), introduced the Local Economic Development Assistance program (LEDA) in 1981. While the LEDA program was initiated just prior to the 1983 election it was wholly embraced by the Progressive Conservatives of Brian Mulroney as seen by their subsequent actions. The LEDA program was created to stimulate private sector employment by providing loan financing, equity capital and advisory services to businesses (EIC, 1983). Initially these development corporations could lend to a maximum of $\$ 25,000$ (RRBDC, 1982). While the program enhanced a community's ability to deal with some of its economic problems it was only targeting small business. The creation of the Community Futures program in 1987, with its accompanying new development corporations, was designed to operate in conjunction with the LEDA corporations already in existence, now called business development corporations (BDC). They were mandated to assess community problems and evaluate the potential for change and recovery (Employment and Immigration Canada 1987). Subsequent to this analysis, an action plan of employment and adjustment initiatives was to be developed to meet the needs of the community. The benefit to business from these efforts included an increase in loan lending limits by BDCs from $\$ 25,000$ to $\$ 75,000$ (C. Milette, 2005). It is clear that the federal government, through EIC, was undertaking the role of providing "access to capital" for business expansions or new business opportunities. The federal government also created FedNor in 1987 to "address economic disparities" and to "encourage growth and diversification, job creation and income generation in 
northern Ontario" (Auditor General, 1995). The program was "targeted toward small and medium-sized businesses" which "involve(d) FedNor assistance under $\$ 100,000$ in the form of contributions" (Ibid). While the contributions, also called grants, provided a means for businesses to access capital they were contentious, as they created a have and have not situation in the business community. Businesses which were in the appropriate sector, e.g. tourism, would be eligible to access the program while others could not. The program, although modified in 1990, followed this approach until it was restructured in 1995 (Ibid).

The restructuring coincided with a change in political leadership following the 1993 election of Jean Chrétien's Liberal government. His government terminated FedNor providing grants to business following a public review and conference in 1995, leading to the position that "assistance to firms would be provided primarily through repayable loans". The government would focus its resources "towards investing in economic development" (Ibid). Thus the lion's share of funds would go towards assisting communities and community based groups in improving their economic circumstances. Today FedNor supports initiatives such as biotechnology, the Northern Ontario School of Medicine, nature-based tourism, telecommunications/e-learning, aviation, youth and the social economy (FedNor, 2005). FedNor has numerous initiatives based on repayable loans in Northern Ontario. Examples include the establishment of loan loss reserves, the capitalization of the CFDCs, the Business Planning Initiative, and the creation of investment pools.

The 1995 restructuring also saw the shift of the Community Futures program from Human Resources Development Canada (HRDC) to FedNor under Industry Canada. In addition to this change in senior government departments, the Community Futures Committees (CFCs) were amalgamated with the BDCs to create the Community Futures Development Corporations (CFDC) (Ibid). As a result of these amalgamations the lending level for the CFDCs was raised from $\$ 75,000$ to $\$ 125,000$ per client. Initially, CFDCs, while very supportive of smaller businesses, did not have the capacity to provide capital at sufficient levels to truly impact the Northern Ontario economy. The creation of the North Eastern and North Western Ontario Investment Pools has provided the basis for CFDCs to make investments up to $\$ 500,000$. In supporting this effort FedNor moved towards making a more meaningful contribution towards access to capital. In the fall of 2005 Industry Canada announced that all CFDCs would be allowed to increase their loan lending limits to $\$ 150,000$.

It is clear from the previous discussion that the federal government has pursued a very haphazard approach in improving access to capital. The shift from contributions to repayable loans leveled the playing field and eliminated handouts to business. Yet the record is unclear as to whether the move improved SME access to capital. 


\section{Access to capital: The provincial response}

It is important to note that the state of the economy affected the policies developed for Northern Ontario. Declining employment in the region had an impact on the policies of the governments of the day, including access to capital which was cited as a major reason why the region was not able to adjust to economic downswings. In addition to the economic conditions, it is important to recognize the governments which ran Ontario over the period considered. This is essential for it is government which sets policy and each government has a different philosophical approach to running the province, including Northern Ontario.

The period under discussion begins with Ontario being governed by the Conservative government of Bill Davis. This government was followed by the brief minority government of Frank Miller who succeeded Davis. The Conservative's 42 year reign was terminated in 1985 by a coalition created by David Peterson's Liberals and Bob Rae's New Democratic Party (NDP). The Coalition governed until a Liberal majority was elected in 1987, led by David Peterson. This government fell to Rae's NDP in 1990 which governed until 1995. The province then took a swing to the far right with the election of the Mike Harris Conservative government in 1995. Harris, and his successor Ernie Eves, governed until the spring of 2003 when they were defeated by Dalton McGuinty and his Liberals. It is safe to say that the province has been alternating from one end of the political spectrum to the other for many years. These changes in government and philosophy have definitely affected policies as they specifically apply to access to capital. Based upon government's perceived needs, Nordev began to offer programs to "establish, expand and modernize small business operations in Northern Ontario" during the 1970s (Nordev, 1980). Ontario continued to stimulate the economy, during the early 1980s, through the "very successful Nordev Program.... and double(d) its funding to \$20 million" (Hansard L001, 1985). Programs such as Nordev were structured to fill the need for access to capital as noted in the statement, "improved access to venture capital in all our regions must be a priority if economic opportunity is to be shared fairly across Ontario" (Ibid). While being touted as successful, the program's budget of $\$ 20$ million dollars seems insufficient to have made a real impact given the size of Northern Ontario.

The government was subsequently encouraged by the Rosehart Advisory Committee Report to increase its role in the northern economy (Rosehart, 1986). This set Ontario on the road towards a more active role in providing capital to business. It should be noted that the majority if not all of this capital was for the major capital costs of a business start up or expansion and did not appear to be for general business loans or operating lines of credit. In 1990, in response to the Rosehart Committee's recommendation to expand Ontario's role in the north, the Liberal government of David Pederson restructured northern development programs and in the process created the Northern Ontario Development Corporation (NODC) 
and the Northern Ontario Heritage Fund Corporation (DCA, 1990; NOHFA, 1990). In 1988 the Minister of Northern Development, the Honourable Rene Fontaine, pointed to the intent of the latter program by suggesting that "one of the major aims of the Northern Ontario Heritage Fund, (is) to provide incentives to create jobs and start or expand small businesses in the north. A portion of this fund will be used to support continuing private sector initiatives under the Nordev program" (Hansard L064, 1988). The NODC was to provide assistance to the private sector "usually in the form of forgivable performance loans or repayable interest bearing loans" (Auditor General, 1995). Clearly, the government was moving to make more capital available to the private sector.

The NODC, while deemed successful by many, was terminated in 1995 by the Conservative government of Mike Harris. This government which had a philosophy of building the economy through the cutting of red tape and the lowering of taxes began its mandate by "opting out of most investment schemes to private businesses" (Doucet, 1997). They chose to use only the NOHFC and changed its mandate, programs and criteria in order to provide assistance to communities and not-for-profit organizations. Ontario did not involve itself in the provision of capital to business from 1995 to 2005 . The 2003 election of the McGuinty Liberals opened the door for a renewed look at the provision of capital in Northern Ontario. This government returned to policies similar to those used prior to the restructuring of the NOHFC in 1995 and, as a result, Ontario is once again providing loans and loan guarantees to northern companies. While the grants to business are still gone, this is an abrupt about face. In addition to providing loans through the NOHFC, the government announced the new Northern Ontario Grow Bonds initiative in February 2005. This program, while similar in some respects to the NOHFC loans, will use capital raised by selling guaranteed bonds to regional residents. The aim is to encourage the region's residents to invest in local business initiatives. Unfortunately, if recent history is correct, these new programs will have a short shelf life, for along with the government's announcements of the new programs, local media also announced impending closures of forestry related operations and paper mills across the north. These closures will surely create a downturn in the region's economy and reduce the need for capital. Business uptake of the capital available through these programs will be poor and result in the programs being terminated or restructured. It appears that the timing of the government's involvement in the provision of capital does not match business needs.

\section{Discussion}

As previously noted there exist challenges which must be addressed if the ongoing issue of access to capital is to be solved. When program timelines and business needs are disjointed there is an apparent disconnect between policy development, implementation and the business environment. For the most part government appears to be out of sync when it comes to the timing of policies designed to address the issue of access to capital. Clearly, to a considerable 
extent addressing access to capital issues has a lot to do with the political perception and ideology of the day. In the case of such programs as NODC and the NOHFC providing capital to business, it was the provincial Liberal party which implemented them while the Conservatives terminated them, regardless of the economic climate of the time.

Reference back to the earlier discussions on provincial programs and program changes it is apparent that the Liberal government of David Peterson introduced the Northern Ontario Development Corporation in 1990 following a decade in which the members of the Canadian Federation of Independent Business ranked access to financing very low on their list of priorities. Less than 20 percent of businesses ranked it as a priority in all years prior to 1991. In fact concerns related to access to capital were near the twenty year low across Canada in 1988. In addition the annual bankruptcy rate was stable in Ontario at about 1700 businesses per annum for the period extending from the release of the Rosehart Report in 1986 to the development of the new NOHFC and NODC programs in 1990 (Figure 2). It should be noted however that Northern Ontario did show an increase in bankruptcies from 124 in 1988 to 205 in 1990 (Figure 3). Unfortunately, even as these programs were being finalized the economy turned for the worst and business failures increased from a low of 1737 in 1987 to a high of 4251 in 1992 (OBS, 2005). Thus the Peterson government developed an access to capital scheme in an economic climate that was very favorable to business, but implemented the initiative at exactly the wrong time; given that it was designed to stimulate the growth of the northern economy and not to stabilize it in bad times.

The inverse was true of the next government, the Conservatives, which terminated the NODC in 1995. This action occurred following a period (1992-1993) when the province experienced the highest levels of business bankruptcy in twenty years (Figure 2). The increase in bankruptcies also increased business requirements for access to capital as seen in the level of concern over the availability of credit as voiced by members of the CFIB, which ranged from below 20 percent in 1992 to over 35 percent in 1994 (Figure 1). The government, citing that it was not its role to invest in business, pulled away assistance in what appeared to be a time of great need and, in the process created an entirely new mechanism to support northern development through the NOHFC. The NODC program was not allowed to evolve to a level sufficient to have a real impact on meeting the capital needs of the business community. It is interesting to note that concerns around the availability of credit did decline to a level of about 30 percent by 1998 and has since remained at this level.

The years of Conservative rule ended when the McGuinty Liberals took over the helm in Ontario in 2003. This government did an about face on access to capital and in the process created new mechanisms for the government to support business. In fact, Ontario announced Grow Bonds and, as previously noted, the Northern Ontario Heritage Fund Corporation's loan programs in the spring 2005. These programs combined with the federally funded Community Futures 
Development Corporations, including their recent $\$ 500,000$ loan pools, as well as access to more traditional lenders, especially the Business Development Bank of Canada (BDC) and credit unions, gives the appearance that the region is in fact well stocked with financial services. If one reviews the CFIB “Our Member's Opinions No. 56" for March 2005 the concerns over the availability of financing was 30.3 percent, down slightly from the 32.3 percent of businesses expressing concern in January 2004. While there is no way of identifying the number of Northern Ontario businesses expressing the same concern over access to capital, it appears that the programs are working at least in the short term.

Federally, Canada announced the FedNor program in 1987, in order to improve the development prospects of Northern Ontario. This program which was also intended to provide capital to northern business, was developed and implemented under the same conditions as the NODC program, however it was announced three years earlier. As the program was being announced and implemented bankruptcies across Ontario were on the rise. The level of northern bankruptcies did not peak until a full year after the province experienced its highest level, indicating a long and more prolonged period of lagging economic conditions in the region. It is interesting to note that the new pool of capital appears to have had little or no effect on the business community since it was not until later, 1990-1994, that access to capital became an important issue to CFIB members. Even though FedNor invested in over 800 projects in Northern Ontario by March 1995, as of December 1994, there was a total of 1,659 bankruptcies reported in the region (Auditor General, 1995). Clearly the program was unable to replace the number bankrupt businesses in the region let alone create economic prosperity. It should also be noted that 52 percent of the recipients of FedNor assistance also obtained financial support for projects through provincial government programs such as Nordev, suggesting a large crossover of clients (Ibid). While business use of the FedNor program was significant, the timing of its implementation just prior to the recession of the early 1990s and the huge increase in business bankruptcies appear to have limited its impact on the region.

\section{Figure 2: Bankruptcies in Ontario}

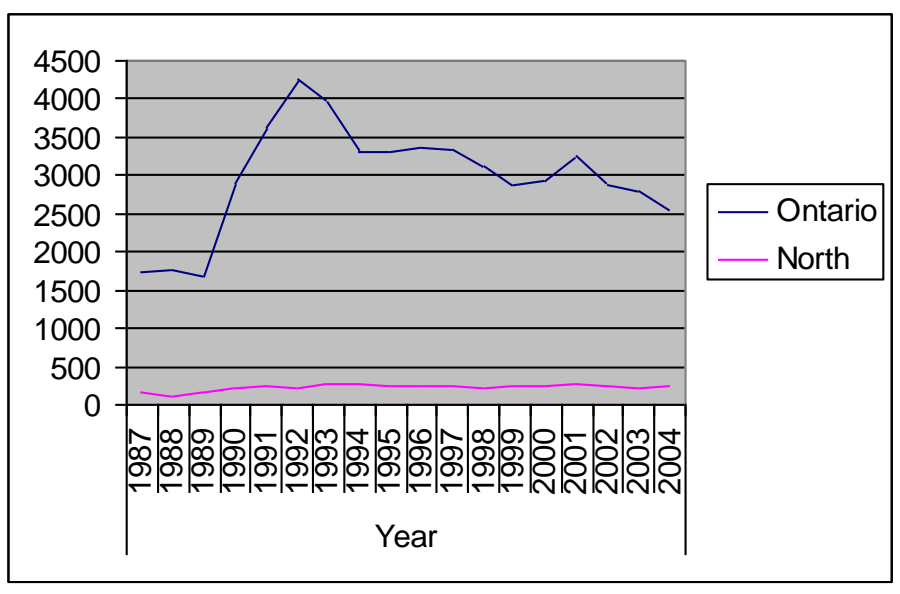

Source: Office of the Superintendent of Bankruptcy Canada, 2004. 


\section{Figure 3: Bankruptcies in Northern Ontario}

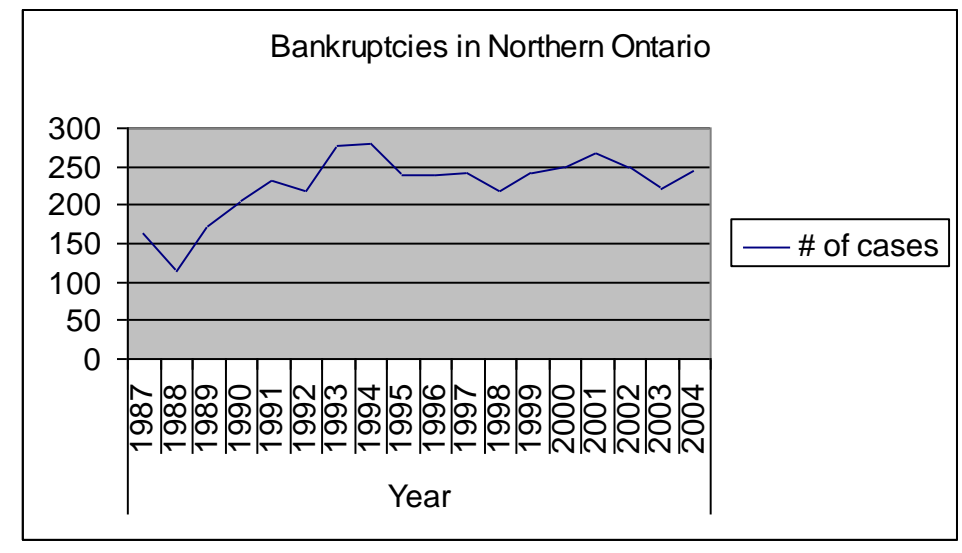

Source: Office of the Superintendent of Bankruptcy Canada, 2004

Access to capital is required in good times in order to start and expand businesses. Most demands for credit during periods of economic stress are likely to be motivated by dire need so it is very difficult to make a strong business case in a declining economy. Unfortunately, even if the aforementioned access to capital measures worked, they were terminated in 1995, long before a clear indication of their impact could be determined. Most access to capital programs were modified or terminated within the span of a few years.

\section{Conclusion}

Clearly, Northern Ontario is continuing to decline economically. After over twenty years of well intended programs by Canada and Ontario the region still faces many years of restructuring. If major industries, such as the pulp and paper industry, continue to close facilities, as observed in 2005, significant investment and operating capital will be needed to revive the region. Sectors such as value added wood products, biotechnology, information technology and aviation which are seen as the hope for the future will not grow and flourish without adequate capital. Government should stop the cycle of well meaning, yet inappropriately structured or timed access to capital programs. Furthermore, greater coordination is required to avoid the implementation of dueling programs. Specifically, programs offered simultaneously by the federal and provincial governments that appear to address the same issue such as was the case of the FedNor and NorDev programs of the late 1980s.

In addition to timing and program similarity, new policies need to focus on providing the appropriate types of capital. A business needs to secure the type of financing that best suits their requirements. Many people echo the need for capital however it is often not exactly clear what type of capital is needed. Most businesses need patient capital, debt capital and operating capital (Bergeron, 1999). A recent study by David van Geem indicates that Northern Ontario is well 
serviced with debt financing. And yet the programs discussed in this paper have primarily assisted business through debt financing. In many cases, increasing debt load is a sure route to bankruptcy. The few programs that can use equity financing rarely do. KPMG in their report of 2001 stated that while "CFDCs are currently able to make equity investments....The use of this capability however, has been limited" (FedNor, 2001).

In addition to banks being wary of small business, especially northern business, a recent survey by the Rainy River Future Development Corporation (RRFDC) found that only one venture capital deal was undertaken in Northern Ontario from 1991 to 2001 (RRFDC, 2003). The activity was a technology project and was funded in North Bay by a labour sponsored venture capital fund. This is tragic given the billions of dollars this industry has to invest across Canada. Given that Northern Ontario receives almost none of the billions of venture capital dollars available in Canada a model similar to an angel investor is needed. Most companies need a significant level of owner or shareholder equity in order to reduce the level of debt financing needed. This is the primary mission of the stock market. For example many firms in more urban areas are able to access shareholder capital. Companies relinquish some control to "the shareholder" in order to place it on firm financial footing. Most companies in Canada and the U.S. operate in an economic environment quite different from that in Northern Ontario where companies do not have the same kind of opportunity to raise funds on the open market. There are very few companies in the region that are public. In the Rainy River District only three companies are public, aside from a few junior mining companies (RRFDC, 2004). Most are either held by a single shareholder or a small group of shareholders with little or no intention of bringing their company public. The tendency to avoid seeking public capital has severely limited regional development. It may be related to the need for control or simply an inability to go public with the company. Venture capitalists expect companies to eventually go public thereby providing the opportunity to recoup their investments. While many venture capitalists require significant rates of return and a solid exit plan, angel investors, be they friends or family, may settle for more modest returns and be quite willing to wait longer periods of time.

While it is not recommended that Canada or Ontario embark on a wholesale purchase of shares in private corporations, they should facilitate the process whenever possible. Senior governments do not appear to be willing to invest in business. Either they are incapable of making effective business decisions or are not in the position to be gambling with taxpayers' money. Even if a government access to capital program does have the capacity to take equity positions they do not as a rule pursue them. For example, a recent FedNor study indicated that while CFDCs can hold this type of position they usually do not do so because they do not generally have the expertise to perform proper evaluations. Ontario's recent Grow Bonds Program, originally intended by its proponents as a government guarantee program for equity investments by northern residents, was implemented as yet another debt financing tool (NOACC, 2003). 
In conclusion, if senior government wishes to continue to support Northern Ontario by increasing the level of capital made available, it needs to introduce a long term strategy. It must also become serious about reducing the level of politically induced change and set about creating a structure which will support business in the long term. Recommended is a regional body similar to the current CFDC structure which lends money to companies at arms length from the general programming of the government. This new structure needs to have a long term commitment in order to weather the economic up and downs of the region. Canada and Ontario need to agree to work more closely together to increase efficiencies, improve expertise and provide better service for their business clients in regions, such as Northern Ontario.

\section{Author's Bibliography}

Geoff Gillon is the Economic Development Officer for the Rainy River Future Development Corporation in Fort Frances, Ontario

\section{References}

Albert-Doucet, Sylvie. (2007). Financial environment for business start-up.

Bergeron, Pierre G. (2009). Finance for non-financial managers: The quickest way to the bottom line. Nelson, Canada.

Canadian Federation of Independent Business. (2003). Banking on competition: Results of CFIB banking survey.

Canadian Federation of Independent Business. (2005). Our member's opinions. (Survey no.25$56)$.

Development Corporations Act, R.S.O. 1990, Chapter D.10.

Employment and Immigration Canada. (1983). Employment and Immigration Canada Contract. .

Employment and Immigration Canada. (1987). Employment and Immigration Canada Contract.

FedNor. (2005). Retrieved from: www.fednor.ic.gc.ca.

FedNor, (2206). Northern spirit: Partners in success.

Industry Canada. (2001). Northern Ontario access to capital study: Final report. 
Industry Canada. (2004). Office of the Superintendent of Bankruptcy Canada. Retrieved from http://strategis.ic.gc.ca/cgibin/sc_mrksv/bankruptcy/statistics/new_bank_s\#THETOP.

Legislative Assembly of Ontario (1985). Hansard (L001). Retrieved from:

http://www.ontla.on.ca/hansard/house_debates/33_parl/session1/L001.htm.

Legislative Assembly of Ontario. (1988). Hansard (L064). Retrieved from:

http://www.ontla.on.ca/hansard/house_debates/34_parl/session1/L064.htm\#P1_0.

(Milette, C, personnel communication, 2005).

Ontario Ministry of Finance. (2001). Census 2001 Highlights.

Northwestern Ontario Chambers of Commerce. (2003). Grow bonds north: A sustainable solution.

Northern Ontario Development Corporation. (1980). Employment Incentives Program.

Northern Ontario Heritage Fund Act, R.S.O.1990. c.N.5.

Northern Ontario Local Training and Adjustment Boards. (2002). Population hanges in Northern Ontario: 1996-2001. 2001 Census Research Paper Series. No. 1.

Rainy River Business Development Corporation. (1982). Contract with employment and immigration Canada.

Rainy River Future Development Corporation. (2003). Venture Capital Review.

Rainy River Future Development Corporation. (1996). Annual Report.

Report of the Auditor General of Canada. (1995). Chapter 21.

Rosehart et al, (1986). Final report and recommendations of the advisory committee on resource dependent communities in Northern Ontario.

Van geem, David. (1998). Financing growth: A northern Ontario perspective: Blindly stumbling down the road to success? Research Issues, Comm 6926. 